\title{
Chondroitin Sulfate A is a Receptor for Plasmodium falciparum- Infected Erythrocyies
}

\section{コンドロイチン硫酸Aは熱帯性マラリヤ原虫感染赤血球のレセプターである}

Key Words : adherence, chondroitin sulfate A, erythrocyies, Plasmodium falciparum

Maternal malaria is a major cause of pregnancy-related complications in endemic areas; it is associated with premature delivery, intrauterine growth retardation, perinatal mortality in the infant, and anemia and death in the mother. Women are particulary susceptible to the malaria durimg the initial pregnancy, even though they may have acquired immunity to the Plasmodium falciparum ( $P$. falciparum) over years of the exposure in endemic areas. In the absence of evidence for other mechanisms, maternal malaria has been attributed to the immunosuppression of pregnancy, which has also led to increased frequency of certain viral infections such as rubella. However, since susceptibility to the infection is markedly lower in maltigravid women than in primigravid women. the immunosuppression could not entirely explain the phenomenon. The authors in this paper introduced here showed that a woman becomes highly susceptible to the infection during her initial pregnancy when she first provides the placental substrate. which selects the chondroitin sulfate A (CS-A)-binding parasites for growth. With successive pregnancies, a woman develops increasing immunity to this parasite subpopulation and reduces the frequency and severity of malaria infection [Fried. M. and Duffy, E. D., (1996) Science, 272, 1502-1504].

Sequestration of $P$. falciparum-infected erythrocytes is central to the pathogenesis of severe $P$. falciparum infection. The process is mediated by specific adherence ligands on the infected erythrocyie surface and host receptors. The placenta is a preferential site for sequestration of the infected erythrocytes and can experience high parasite densities, while the peripheral circulation is free of parasites. In other vascular beds, $P$. falciparum-infected erythrocytes adhere to the endothelial surface; endothelial surface molecules such as thrombospondin, CD36, ICAM- 1 (intracellular adhesion molecule-1). VCAM1(vascular cell adhesion molecule-1), and E-selectin are known to support the infected erythrocytes adhesion in vitro. CS-A, which is a glycosaminoglycan enriched in disaccharide units of GlcA-GaINAc(4-O-S), has been recently identified as another receptor for the infected erythrocytes [Rogerson, S. J., Chaiyaroj, S.C., Ng. K., Reeder, J. C., and Brown, G. V., (1995) J. Exp. Med., 182, 15-20]. [Robert, C., Pouvelle, B., Meyer, P., Muanza, K., Fujioka, H., Aikawa, M., Scherf, A., and Gysin, J., (1995) Res. Immunol., 146, 383-393].

The infected erythrocytes obtained from human placen-
母性マラリヤは、ある地方特有の妊娠に関連した合併症の 主要な原因であり、早産、胎児の子宮内成長不全や死産、母親 の貧血や死亡を起こすこともある。たとえ何年間もその地方で 生活し、熱带性マラリヤ原虫に対する免疫を獲得していたとし ても、最初の妊娠をした女性は特にマラリヤに感染しやすくな る。何の証明もないが、これは妊娠による免疫抑制のためで、妊 婦が風疹のようなウィルスに感染しやすくなるのと同じことで あろうと考えられていた。しかし、何回も妊娠をした女性は最 初の妊娠をした女性よりもマラリヤの感染率が顕著に低い現象 を、免疫抑制だけでは説明することはできなかった。ここで紹 介する論文の著者たちは、初めて妊娠した女性の胎盤の基質が、 コンドロイチン硫酸 A (CS-A) 結合性マラリヤ原虫の選別と成 長の場となることを示した。二回目以降の妊娠では女性がこの CS-A結合性寄生虫群に対するより強い免疫を獲得し、マラリヤ 感染の頻度や重さが軽滅される [Fried, M. and Duffy, E. D., (1996) Science, 272, 1502-1504]。

熱帯性マラリヤ原虫感染赤血球の遮蔽が、マラリヤの主要 な病因である。この過程は感染赤血球の特異的レガンドと宿主 レセプターとの結合によってもたらされる。胎盤は感染赤血球 の絶好の遮蔽場所であり、末梢循環に存在していなくても、胎 盤には高密度にこの寄生虫が存在することがある。他の血管床 では、感染赤血球はトロンボスポンジン、CD36、ICAM-1 (intracellu1ar adhesion molecule-1)、VCAM-1 (vascu1ar cell adhesion molecule-1)、E-セレクチンのような内皮表面分子に結合す ることが知られている。最近、グリコサミノグリカンで GlcA GalNAc (4-O-S) の二糖体単位構造に富んだ CS-A が感染赤血球 のもう一つのレセプターとして同定された [Rogerson, S. J., Chaiyaroj, S. C., Ng, K., Reeder, J. C., and Brown, G. V., (1995) J. Exp. Med., 182, 15-20], [Robert, C., Pouvelle, B., Meyer, P., Muanza, K., Fujioka, H., Aikawa, M., Scherf, A., and Gysin, J., (1995) Res. Immunol., 146, 383-393]。

ヒトの胎盤からの感染赤血球は固定化したCS-A と結合す 
tas bound to immobilized CS-A but not CD36. Conversely. the infected erythrocytes from peripheral circulation of nonpregnant donors adhered to CD 36. but not to CS-A. The placental infected erythrocytes bound to sections of fresh-frozen, uninfected human placenta. The binding was competitively inhibited by CS-A in solution, but not CS-C and CS-B (dermatan sulfate). The same effect was obtained by pretreatment of the tissue sections with chondroitinase AC. which acts endolytically on CS-A and CS-C. Those results suggested that maternal malaria arises when the placenta selects for a parasite subpopulation that binds to CS-A.

The marked difference in inhibition of the binding by CS-A compared with CS-B and CS-C was surprising. The sulfation pattern and the proportions of glucuronic acid and its epimer, iduronic acid, in those CS chains are very variable. CSA contains predominantly disaccharide units composed of GlcA and GalNAc(4-O-S). Whereas CS-C contains predominantly GlcA-GalNAc(6-O-S) disaccharide units. CS-B contains high proportion of IdoA instead of GlcA. Although the current studies did not elucidate the specific oligosaccharide sequence that supports the binding to the ligand on the placental infected erythrocytes, it appears to involve a specific domain structure present in CS-A that occur infrequently in the CS-B or CS-C preparations used. Such a specific oligosaccharide sequence can be clarified only by studies using well-defined oligosaccharide preparations.

The discovery that CS-A can be a specific adherence receptor for subpopulation of $P$. falciparum added a new knowledge on interactions of the infected erythrocytes and host adhesion molecules and on their relevance to the pathogenesis of severe malaria. Thus, the malarial cytoadherence, like leukocyte adhesion, may involve both protein and carbohydrate receptors and offer a new approach to investigating the relationship between adherence and disease severity that has proved so elusive. In addition, the novel finding that CS-A may act as a specific receptor for an infectious agent is of general interest, expanding the established roles of glycosaminoglycans in cellcell and cell-matrix interactions.

\section{Reported by Ishihara, $M$.}

National Defense Medical College

Research Institute,

Namiki 3-2, Tokorozawa-shi, Saitama, 359 Japan

FAX: 81-429-91-1611
るが、CD36とは結合しない。反対に、妊娠していない提供者の 末梢循環からの感染赤血球はCD36 と結合するが、CS-A とは結 合しない。胎盤からの感染赤血球は、新鮮な非感染七卜胎盤の 凍結切片に結合する。この結合は競合的にCS-A溶液により阻害 されるが、CS-CやCS-B（デルマタン硫酸）では阻害されない。 CS-A P CS-C を末端で分解するコンドロイチナーゼ ACでその 組織切片を事前処理することにより、同じ様な効果が得られた。 これらの結果は、母性マラリヤは胎盤がCS-A結合性マラリヤ原 虫の一群を選別する時に発生することを示唆している。

このCS-A による結合阻害効果が、CS-B や CS-C と比べて 顕著に高いことは驚きである。これらのCSにおける硫酸化のパ ターンやグルクロン酸とそのエピマー体であるイズロン酸の比 率は大きく異なっている。CS-A は主に GlcA と Ga1NAc（4-OS）よりなる二糖体単位よりなり、CS-C は主に G1cA-Ca1NAc (6-O-S) 二糖単位を含んでいる。CS-B はGlcAに代わって、IdoA を高比率で含んでいる。現在の研究は、胎盤からの感染赤血球 のリガンドと結合する特異的オリゴ配列を明らかにしないけれ ども、CS-Aには使われた CS-B P CS-Cにはほとんど存在しな い特異的なドメイン構造を含んでいると考えられる。そのよう な特異的オリゴ糖配列の決定には、既知の構造をもつ一連のオ リゴ糖断片を使用する必要がある。

CS-A が一群の熱帯性マラリヤ原虫のためのレセプターで あるというこの発見は、感染赤血球と宿主結合分子との相互作 用、そして重いマラリヤの病理に関する新しい知見を加える。 すなわち、白血球の細胞接着のようにマラリヤの接着にはタン パク質と炭水化物レセプターの両者が関与している。さらに、 これらの成果は暖昧であった接着と病気の重症度についての相 関を調べる新たなアプローチを与えることになる。加えて、CSAが感染因子の特異的レセプターであるという新規の発見は科 学一般にも大変興昧深く、知られている細胞 - 細胞間あるいは 細胞 - マトリックス間の相互作用に扔けるグリコサミノグリカ ンの役割についての知見を広げるものである。

防衛医科大学校・防衛医学研究センター

石原 雅之 